?

\title{
The Counts of Laval
}

Culture, Patronage and Religion in Fifteenth-and Sixteenth-Century France

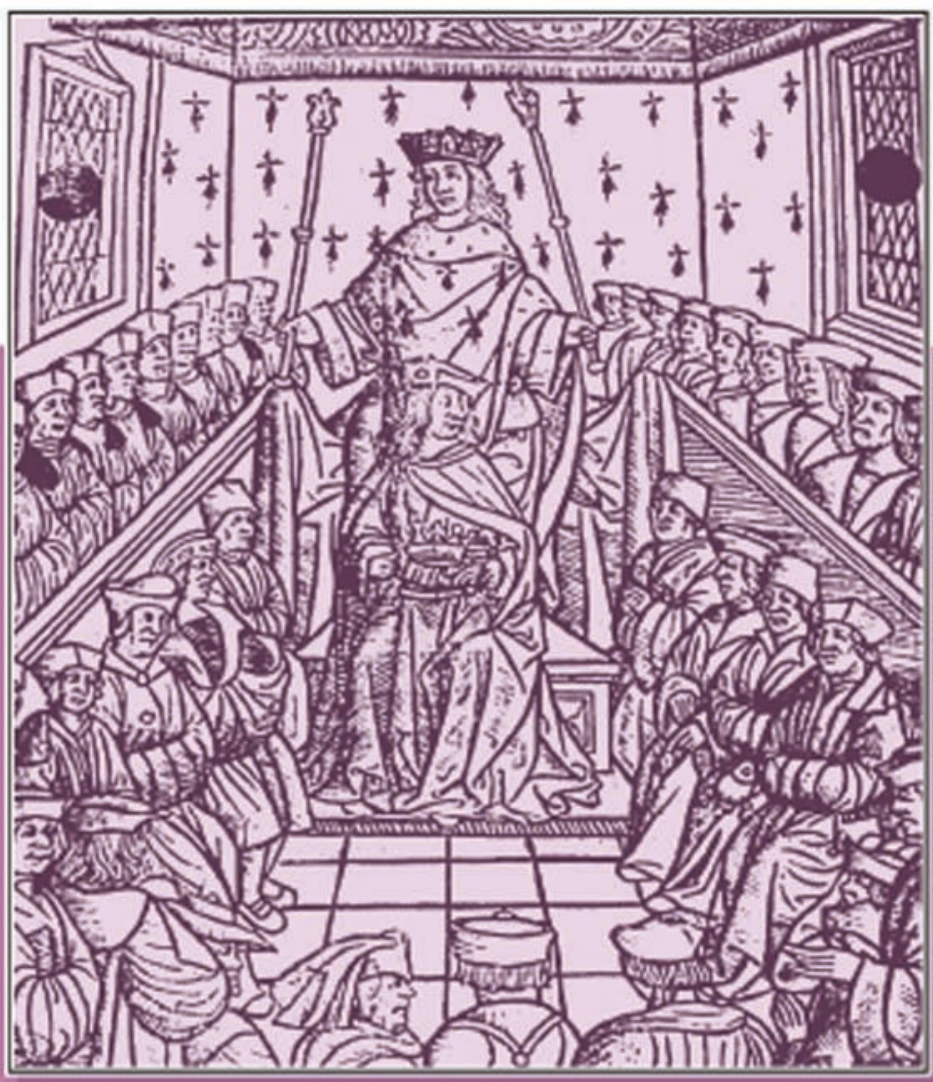

Malcolm Walsby 
THE COUNTS OF LAVAL 
$\because$ Taylor \& Francis

Taylor \& Francis Group

http://taylorandfrancis.com 


\title{
The Counts of Laval
}

Culture, Patronage and Religion in Fifteenthand Sixteenth-Century France

\author{
MALCOLM WALSBY \\ University of St Andrews, UK
}

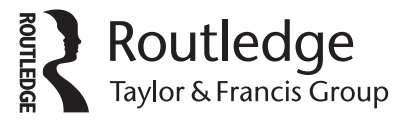

LONDON AND NEW YORK 
First published 2007 by Ashgate Publishing

Published 2016 by Routledge

2 Park Square, Milton Park, Abingdon, Oxon OX14 4RN

711 Third Avenue, New York, NY 10017, USA

Routledge is an imprint of the Taylor \& Francis Group, an informa business

Copyright (C) Malcolm Walsby 2007

Malcolm Walsby has asserted his moral right under the Copyright, Designs and Patents Act, 1988 , to be identified as the author of this work.

All rights reserved. No part of this book may be reprinted or reproduced or utilised in any form or by any electronic, mechanical, or other means, now known or hereafter invented, including photocopying and recording, or in any information storage or retrieval system, without permission in writing from the publishers.

Notice:

Product or corporate names may be trademarks or registered trademarks, and are used only for identification and explanation without intent to infringe.

\section{British Library Cataloguing in Publication Data}

Walsby, Malcolm

The Counts of Laval : culture, patronage and religion in fifteenth- and sixteenth-century France 1.Laval(Family)2.Patronage, Political-France-History-16thcentury 3.Patronage, Political - France - History 4.France - History -15 th century 5.France - History -16 th century 6.France - Religion

I.Title

944'.026

\section{Library of Congress Cataloging-in-Publication Data}

Walsby, Malcolm.

The counts of Laval : culture, patronage and religion in fifteenth and sixteenth-century France / Malcolm Walsby.

p. cm.

Includes bibliographical references and index.

ISBN-13: 978-0-7546-5811-5 (alk. paper)

1. Laval, Counts of. 2. Nobility-France-History. 3. Protestants-France-History. 4. FranceHistory-Wars of the Huegenots, 1562-1598. 5. France-Social life and customs. 6. FranceReligious life and customs. I. Title.

DC36.8.L34W35 2007

944'.026-dc22

ISBN 13: 978-0-7546-5811-5 (hbk) 


\section{Contents}

List of Illustrations and Maps

vii

Acknowledgements

Preliminary notes

Introduction

1 Mediaeval Lords: The Rise of the House of Laval

2 The Network of Affinity

3 The Golden Age

4 New Challenges: The Wars of Religion

5 Laval versus Rohan

Conclusion

Appendix: Genealogy Tables

Index 
$\because$ Taylor \& Francis

Taylor \& Francis Group

http://taylorandfrancis.com 


\section{List of Illustrations and Maps}

1.1 Map of main lands of Lavals in western France 15

1.2 Map of Laval lands in fifteenth century Brittany 22

1.3 Evolution of the arms of the Lavals 36

2.1 The network of affinity 50

3.1 Map of Laval lands in Brittany under Guy XVI and Guy XVII 83

3.2 Courtyard of Laval castle 99

$\begin{array}{ll}3.3 & \text { The new castle built by Guy XVII } \\ 3.4 & 100\end{array}$

$\begin{array}{lll}3.4 & \text { Vitré castle } & 101\end{array}$

3.5 Vitré castle from the faubourg St Nicolas 102

4.1 Map of Laval lands in Brittany during Wars of Religion 122

5.1 Map of Laval and Rohan lands in Brittany in 1510152

5.2 Judgment given by the duke of Brittany at the meeting of the Estates in 1451 - Woodcut from Les grandes croniques de

Bretaigne by Alain Bouchart (Galiot du Pré, Paris, 1514) 
$\because$ Taylor \& Francis

Taylor \& Francis Group

http://taylorandfrancis.com 


\section{Acknowledgements}

Many historians, archivists and librarians have helped me in the course of my research and in the formulation of this book. Foremost amongst these is David Potter, who guided my first steps into the world of fifteenth- and sixteenth-century France. His intellectual rigour and analytical approach have served me well on many occasions. Both Michael Jones and Michel Nassiet have shared with me their unrivalled knowledge of late mediaeval and early modern Brittany and its nobility. I would also like to thank them for their continued support and encouragement. More recently, I owe a great debt to Andrew Pettegree. Not only has he helped me with his advice but has also spent considerable time discussing my ideas, often in some far flung corner of France as we worked together in a Bibliothèque Municipale. My understanding of the Reformation world has increased immeasurably through our innumerable conversations. Alexander Wilkinson, now of University College Dublin, Sara Barker and all the other members of the French Vernacular Book Project of the University of St Andrews have at some point pushed an unknown reference my way. I would also like to thank Dominique Eraud, director of the Inventaire du Patrimoine in Laval who has very kindly allowed me to use some of his photos in this book. Alban Gautier has been both a great friend and a valuable sounding board for my ideas. For the last decade, my parents, brother and sister have all had to put up with me endlessly talking of the house of Laval and fifteenth- and sixteenth-century France. Their forbearance has been remarkable and I cannot thank them enough. Finally, I would like to acknowledge the unwavering support and the patience of my wife, Aude. 
$\because$ Taylor \& Francis

Taylor \& Francis Group

http://taylorandfrancis.com 


\section{Preliminary notes}

The livre tournois was the basic currency during the fifteenth and sixteenth centuries. There were, however, also other currencies in use and most notably the livre Breton and the écu, which fluctuated in value when compared to the livre tournois. ${ }^{1}$ The livre was subdivided into 20 sous, and each sous was subdivided into 12 deniers.

All the barons and later counts of Laval changed their name to Guy when they inherited the dignity. For the uninitiated this can be somewhat confusing. During the fifteenth and sixteenth centuries the head of the family was Guy XII (13481412), Guy XIII (1412-1414), Guy XIV (1414-1486), Guy XV (1486-1501), Guy XVI (1501-1531), Guy XVII (1531-1547), Guyonne and Guy XVIII (1547-1567), Guy XIX (1567-1586) and Guy XX (1586-1605).

1 For the use of the livre tournois see Potter, D., A History of France 1460-1560: The Emergence of a Nation State (London, 1995) p. xvi. Values of the écu varied: 36s 3d (1498), 40s (1516), 45s (1533), 50s (1551), 60s (1574). The Breton livre was generally worth 1.2 livres tournois but any genuine equivalences are beset by difficulties (Leguay, J.-P., Fastes et malheurs de la Bretagne ducale, 1213-1532 (Rennes, 1982) pp. 237-238). 
$\because$ Taylor \& Francis

Taylor \& Francis Group

http://taylorandfrancis.com 


\section{Introduction}

The Lavals were one of the most powerful noble houses of fifteenth- and sixteenthcentury France. By the start of the fifteenth century, they had gradually risen to become the most important family in Maine and Eastern Brittany. They had developed a strong tradition of royal service and maintained a careful balance between the dukes of Brittany and the kings of France. However, during the final decades of the Hundred Years' War, the counts backed the French cause and invested heavily to ensure success in the battles that raged against the English north of the Loire. The triumph of Charles VII ensured that this investment was well rewarded as the family received both honours and administrative and military positions. By the end of the century, the house of Laval had reached a quasi princely status and, with vast lands throughout north-western France, the family had developed a large affinity. Yet the end of the century was to bring a new challenge: the unresolved problem of the succession of duke Francis II of Brittany (1458-1488) created an atmosphere of instability that made maintaining a neutral stance between an increasingly powerful king of France and a weakened Brittany difficult. Once more the Lavals made an astute choice, quietly backing the unification of the kingdom and the duchy and thus strengthening their position both as independent lords and as representatives of royal authority.

The disappearance of the ducal court after the last Duchess of Brittany, Anne, had accepted marriage with the French king created a new power dynamic in western France. Inevitably, the leading noble families acted to fill the void. It was in these auspicious circumstances that Guy XVI de Laval assembled one of the most dazzling princely courts of Renaissance France. He astutely mixed his own personal patronage and the power he had obtained as governor, lieutenant general and admiral of Brittany to gather around him an impressive entourage that included representatives of most of the leading families of the region, both noble and urban. His son followed his example, initially under the tutelage of his uncle Anne de Montmorency. As Guy XVII, he further built the family fortunes, not least through a successful career at court and his friendship with the dauphin, the future Henry II. This was a truly golden era for the counts de Laval and their affinity and by the middle of the sixteenth century two centuries of bold and incisive dynastic politics had brought the Lavals close to acceptance as one of France's leading families.

Yet the perils of dynastic politics would be demonstrated by the speed with which the family fortunes declined after the death of Guy XVII in 1547. Guy XVII left no male heir and the patrimony of the house of Laval passed to his niece Guyonne. The inheritance sparked off a period of bitter fighting with her husband for the control and administration of the lands and this undermined the family's standing. Guyonne made an already difficult situation far worse by adopting the Calvinist faith. The 
start of the Wars of Religion severely tested the family's tradition of loyal service to the monarch. During the 1550s and 1560s an increasing number of nobles had been touched by the Reformation message and the Lavals were one of the most important families to adhere to the new faith. In the lands that they owned, the local population remained staunchly Catholic and, along with the family of Rohan, they were the sole beacon of Protestantism in Brittany and Maine. They established in the town of Vitré the only Protestant stronghold in north-western France. Thanks to their military reputation, their considerable wealth and their close links to the Montmorencys and Colignys, the family of Laval was considered to be a vital component of the Protestant leadership.

The religious choices made by the Lavals had important repercussions. By choosing the rebel camp the family put in jeopardy many of the privileges and advances that had been so painstakingly obtained over the previous centuries. Their religious choice also threatened to alienate the vast majority of the inhabitants of their lands and undermined the web of clientage that the counts had so carefully woven. Furthermore, they opened their lands and assets to the attacks of Catholic troops and gave their vassals an opportunity to usurp new rights and release themselves from their obligations. The price to be paid for their conversion was thus very considerable, but the new faith also brought with it a range of new opportunities that to some extent balanced the damage done. While some traditional relationships were not maintained, Calvinism created its own clientage network which drew many new men into the Laval orbit. The second half of this study analyses the way in which the Lavals dealt with the new challenges of the Wars of Religion, and sought to maintain their position in these most troubled times.

Nothing preoccupied the Lavals more over these two centuries than their relations with social equals and inferiors. Cultivating an affinity or clientage played a role in almost every aspect of their business and will be a central theme of this study. The ways in which members of the nobility related to each other and to other members of society have been the object of considerable recent debate amongst historians. The last centuries of the Middle Ages saw a transformation in the nature of feudal obligations between members of the nobility and the emergence of more flexible relationships. Yet scholars have struggled to develop a persuasive conceptual model to describe this new system. The use for example of the expression 'bastard feudalism' favoured by some English historians does not have much resonance in the French historical context where these new relationships were not based on written contracts. ${ }^{1}$ Instead a range of terms has been proposed to catch the essence of this new system: clientage, patronage, affinity and fidelity all have their advocates. In

1 John Russell Major did use this expression: 'Bastard feudalism and the kiss: Changing social mores in late medieval and early modern France', Journal of Interdisciplinary History, 17 (1987) 509-535, but thereafter abandoned it. For a comparison of the two systems see Lewis, P.S., 'Decayed and non feudalism in later medieval France', Bulletin of the Institute of Historical Research, 37 (1963) 157-184. 
consequence, much of the subsequent historiography has been preoccupied with defining, counter defining and redefining the vocabulary rather than concentrating on the phenomenon itself. ${ }^{2}$ Detailed studies of the clientage or affinity of major noble families at the end of the middle ages and during the sixteenth century have actually been few and far between.

The noble household has attracted a degree of attention; for the fifteenth century one can read the excellent book by Mattéoni on the dukes of Bourbon and by Gonzalez on the duke of Orléans. ${ }^{3}$ But here we will attempt to go beyond the boundaries of the count of Laval's household and analyse the whole of the affinity. This wider brief will enable us better to comprehend the scope of the family's power and influence. By examining the clientage of a great aristocrat over two centuries, it will be possible to refine our understanding of the relationship between local families and the Lavals and to trace the evolution of this relationship as well as analyse a variety of individual careers. By extending the discussion through both the fifteenth and sixteenth centuries this book will also, I hope, help to challenge the assumption that one belonged to the mediaeval era whilst the other was part of a very different Early Modern period. Society, its structures and the relationships between individuals, did not suddenly change. A nobleman in the sixteenth century thought, lived and interacted with other members of society in much the same way as his great-grandfather had.

If the sixteenth century did bring dramatic change, this was especially so with regard to religion. The Reformation had a strong impact on the house of Laval and all those who tied their fortunes to those of the family. The conversion of the Lavals and its effects will, therefore, inevitably form an important part of our analysis. These events will also provide an unusually dramatic canvas on which to sketch a response to a far older but still enduring debate about the whole status of nobility in mediaeval and modern society. The old idea of a crisis of the nobility no longer has great currency. ${ }^{4}$ Indeed, we now tend to assume that the nobility as a whole not only

2 See the exchange between Kettering ('Patronage in early modern France', French Historical Studies, 17 (1992) 839-862; Patrons, Brokers and Clients in Seventeenth-Century France (New York, 1986), 'Clientage during the French Wars of Religion', Sixteenth Century Journal, 20 (1989) 221-239, 'Friendship and clientage in early modern France', French History, 6 (1992) 139-158)) and Neuschel (Word of Honor: Interpreting Noble Culture in Sixteenth Century France (New York, 1989), The Prince of Condé and the Nobility of Picardy: a Study of the Structure of Noble Relationships in Sixteenth Century France (Thesis, Brown, 1982)) as well as the synthesis by Arlette Jouanna: 'Réflexions sur les relations inter nobiliaires en France au XVIe et XVIIe siècles', French Historical Studies, 17 (1992) 872881.

3 Mattéoni, O., Servir le prince. Les officiers des ducs de Bourbon à la fin du MoyenAge (1356-1523) (Paris, 1998); Gonzalez, E., Un prince en son hôtel: les serviteurs des ducs d'Orléans au XVe siècle (Paris, 2004).

4 Vaissière, P. de, Gentilshommes campagnards de l'ancienne France (Paris, 1904); Drouot, H., Mayenne et la Bourgogne. Etude sur la ligue (1587-1596) (Dijon, 1937); Febvre, L., Philippe II et la Franche-Comté (Paris, 1911); Goubert, P., Beauvais et les Beauvaisis de 
overcame any obstacles put in their way, but even profited from the civil wars. ${ }^{5}$ In this context, it will be important to see how the Lavals fared as a great Protestant family in an overwhelmingly Catholic area and look at how their clientage reacted to these circumstances. This will also enable us to consider the events of the Wars of Religion in western France from the perspective of a noble leadership that simultaneously played a vital role in sustaining the cause and did much to undermine it. This latter issue is examined in particular through the analysis of the relationship between the houses of Laval and Rohan, two Protestant families with shared loyalties but with rival dynastic ambitions.

The work presented here is the result of a decade of archival research in archives in western France, Paris and the United Kingdom. Up until this point, the absence of a central archival repository has discouraged any modern scholarly engagement with the Lavals. Over the centuries the house of Laval had centralised its charters, registers of accounts and other documents in a handful of castles. These were collectively known as the 'trésor des comtes de Laval' and the most substantial collections were kept in the 'tour des archives' in Vitré and in the main tower of the castle of Laval, where one can still see the iron rings from which the bags of parchment and paper hung. The documents that were thus preserved were a vital resource for the family's lawsuits. They contained the legal justification for all their rights and privileges as well as many genealogical details that enabled them to lay claim to the inheritances of collateral members of the family. Their value was such that they were jealously guarded and kept under lock and key. ${ }^{6}$ The trésors were initially damaged during the wars of the Catholic League, when a number of the count's castles were ransacked. The count's guardian complained in 1590 that in some of his lands the archives had been specifically targeted and many documents had been stolen or destroyed. ${ }^{7}$ But if these depredations were significant, it was during the French Revolution that the most serious losses occurred. The La Trémoïlles, who inherited the lands of the Lavals, gathered together virtually the entirety of the papers in the castle in Laval

1600 à 1730: Contribution à l'histoire sociale de la France du XVIIe siècle (Paris, 1960). See also Bitton, D., The French Nobility in Crisis, 1560-1640 (Stanford, 1969).

5 Wood, J.B., The Nobility of the Election of Bayeux 1463-1666, Continuity through Change (Princeton, 1980; Russell Major, J., 'Noble income, inflation and the Wars of Religion in France', American Historical Review, 86 (1981) 21-48; Constant, J.-M., Nobles et paysans en Beauce aux XVIe et XVIIe siècles (Thesis, Lille, 1981); Boucher, J., Société et mentalités autour de Henri III (Thesis, Lille, 1981).

6 This in itself could cause problems, during a lawsuit it was explained that 'le tresor des lettres de ladicte baronnye de Vitré est fermé soubz clef et sceaulx et que les officiers de ladicte baronnye n'y aultres du conseil dudict seigneur opposant n'ont entre mains les anciens adveuz, tenues, tiltres et engagements': Lawsuit against the lord of Espinay, 26 March 1576, AN AA 60. The use of the term trésor was common: Olland, H., La baronnie de Choiseul à la fin du moyen âge (1452-1525) (Nancy, 1980) p. 131.

7 Request made to the Rennes Parlement, 28 July 1590, AD Ille-et-Vilaine, 1 F 1257. 
in the seventeenth century. ${ }^{8}$ Unfortunately, during one of the royalist revolts the archives of the castle were dragged out into the courtyard and burnt.

Recreating the archives of the Lavals is a task that starts with the papers that were taken to the La Trémoïlles' castle of Thouars and are now mostly kept either in the 'papiers de l'émigré La Trémoïlle', seized at the revolution, or in the chartrier of Thouars. ${ }^{9}$ Additionally, archivists in various departmental archives, most notably those of Mayenne, have sought to recreate, thanks to acquisitions, donations and new discoveries some of the original trésor of the Lavals. The most important collection in this respect was that donated by the historian Arthur Le Moyne de La Borderie to the archives of Ille-et-Vilaine. Born in Vitré, he gathered together a substantial amount of original documents, the vast majority of which have hitherto remained unexploited. Elsewhere, the marvellous collection of the Bibliothèque Nationale in Paris also holds many documents relating to the Lavals, including letters kept by those who had corresponded with the counts. The numerous lacunae that subsist after one has trawled through all these archives can be partially filled by consulting more generic sources. For this study, I have used a number of contemporary memoirs and descriptions of events, as well as a large variety of printed sources described below. I have also found valuable additional information in the registers of judicial institutions such as the Parlements in Rennes and Paris and the reports of English correspondents now to be found in the National Archives in London. Thanks to all these dispersed sources, one can gradually fill in the gaps and reconstruct the history of the house of Laval in the fifteenth and sixteenth centuries - a history hitherto unknown.

The comparative lack of interest in the house of Laval in recent centuries contrasts with their contemporary renown. This is reflected both in their elevated position in most contemporary chronicles and in a number of early historical works dedicated to the family. The first work of importance that was written on the Lavals dates from the end of the fifteenth century when a servant of one of the younger brothers of Guy XV composed a sumptuously illustrated panegyric. ${ }^{10}$ This was followed by a history of the barons of Vitré by Pierre Le Baud. This became a well known text thanks to a much later edition of Le Baud's work by Hozier at the beginning of the seventeenth century which also included the sequel written by Jean Gesland, another servant of the family, who took the story on up to the second half of the sixteenth century. ${ }^{11}$ To these writings one must also add the chronicle written by Guillaume Le Doyen, a notary of the town of Laval. For over fifty years Le Doyen kept a journal that became the basis of an extended verse chronicle which is full of surprising details and useful

8 The inventory drawn up for the La Trémoilles is annotated to indicate where the documents should be kept: AN 1 AP 1760.

9 See the inventory: Samaran, C., Archives de la maison de La Trémoille (Paris, 1928).

10 Publitius, J., Panegyricus domus Lavallensis (written between 1473 and 1493, BnF Lat. 7809).

11 Le Baud, P., Chronique de la maison de Vitré and Gesland, J., Addition à la Chronique de Le Baud (ed. d'Hozier, Paris, 1638) [BnF, Rés. Fol Lk2 448]. 
anecdotes and remarks. The text also includes a manuscript copy of a very rare printed book written by Jean Daniel on the funeral of Guy XVI de Laval, originally printed in Angers in 1531. ${ }^{12}$

Other contemporary accounts, include that of Jean de Gennes of Vitré who noted down in his journal all the dates of birth, marriage and death of all of the Lavals as well as describing other events involving the family like his long account of the entry of Guy XVI's second wife, Anne de Montmorency, into the town in $1517 .{ }^{13}$ However, it is the writings of Jean Legeay that are of most use to this study. This nobleman was brought up at the court of Guy XVI in the first decades of the sixteenth century and wrote two texts that described at some length the court and lives of the counts de Laval. The first, a panegyric of Guy XVII, is unfortunately lost and we rely instead on his second work, a history of a family close to the Lavals. When writing this history, Legeay described in great detail what life was like at the court of the counts, and though only fragments survive, this is a vital source of information that paints a vivid and lively picture of the court. ${ }^{14}$

For the purposes of this book, I have also been able to draw on a wide variety of incidental references which I have accumulated through a wide-ranging survey of contemporary literature in the course of an exhaustive analysis of the entire corpus of printed polemical and literary works published in the fifteenth and sixteenth centuries. It transpires there are indeed few general contemporary books that do not mention in some way the Lavals. ${ }^{15}$ The miscellaneous references obtained give us a glimpse of the radiance of the house and often offer extra details that cannot be deduced from the manuscript sources. Most notably they demonstrate the impact of the Lavals as cultural patrons. I have been able to find more than two dozen books explicitly dedicated to a member of the immediate family of the count. These include, for instance, François Hotman's commentaries on Caesar's De Bello

12 Le Doyen, G., Annalles et Chronicques du pais de Laval et parties circonvoisines (ed. Morin de La Beauluère, L.-J., Laval, 1859); Daniel, J., L'ordre funèbre et pompe pitoyable tenue à l'enterrement de M le comte de Laval (Angers, 1531), the only known surviving copy is incomplete: BM Laval 30927.

13 Paris-Jallobert, P., Journal historique de Vitré ou documents et notes pour servir à l'histoire de cette ville (Vitré, 1880) contains extracts from the original journal (BnF NAF 1723).

14 Legeay, J., Au lecteur de bonne volonté sur les louanges des grandes alliances, antiquité, singularités de l'illustre florissante et très heureuse maison d'Espinay extracts were published in Busson, H., Charles d'Espinay, évêque de Dol, et son oeuvre poétique: 15311591 (Paris, 1923); La Borderie, A. de, 'La Trémoïlle et Laval-Vitré', Revue de Bretagne \& de Vendée, 32 (1888) 120-134 (this version modifies the original spelling and has breaks that are not indicated in the text), and Clouard, E., (ed.) 'Deux bourgeois de Vitré, journal inédit', Revue de Bretagne, (1914) 197-237. The manuscript copy of the first 32 pages (AD Ille-etVilaine, $5 \mathrm{~J} 168$ ) is both longer and more reliable.

15 This has been achieved in the context of my work with the French Vernacular Book project of the University of St Andrews. 
Gallico, dedicated to Guy XIX. ${ }^{16}$ There are also a number of contemporary printed texts partially devoted to the house of Laval. There are chapters on the counts in various works, such as Simon Marion's Plaidoiries, a miscellany of notable cases which included one in which the Lavals were directly involved. The Lavals also feature in a book discussing various claims to the kingdom of Sicily and Jerusalem. ${ }^{17}$ Finally, the conversion of the last count of Laval to Catholicism caused an extended pamphlet exchange between delighted Catholics and disappointed Protestants. The importance of all these printed sources is enhanced by the recent discovery in an Amsterdam bookshop of a printed decision of the Parlement on a lawsuit on the inheritance of Guy XX. This book gave an account of the final few years of the last count of Laval, and filled in some of the lacunae that subsisted after all other sources had been consulted. ${ }^{18}$

After the death of the last count of Laval in 1605, the interest of contemporaries quickly receded. The first historical work of note was by Vincent Quereau, a lawyer of Laval, who, in a work dedicated to a La Trémoïlle, mixed the general history of the world since its inception and that of the counts of Laval. This useful if summary work was followed by Du Chesne's history of the house of Laval that was published with his history of the house of Montmorency. ${ }^{19}$ But it was not until the writings of Jacques Le Blanc de la Vignole that a genuinely interesting history of the family was penned. This notary from Laval gathered together an impressive array of documents to which he added the knowledge passed on to him first hand by the 'anciens' when he was young. The longevity of Le Blanc de La Vignole (1601-1684) enabled him to include important witness accounts that complement his own archival work. He drew on all this to write a 'Histoire généalogique de la maison de Laval' comprising an analytical volume and nine volumes of documents. It was never published and by the outbreak of the Revolution, there was only one full copy known - a text considered so valuable that, ironically, it was housed with the archives themselves and therefore

16 Hotman, F., C. Julii Caesaris de Bello Gallico Commentarii, (Lyon, 1573) [British Library, C.80.f.7].

17 'Pour Monsieur le comte de Laval; sur la mouvance féodale du comté de Quintin', (pp. 239-326 in Marion, S., Plaidoyez de Maistre Simon Marion, baron de Druy, cy devant advocat en Parlement et de présent conseiller du Roy en son conseil d'estat et son advocat général (Michel Sonnius, Paris, 1598) [BnF, Résac. F 39606]); de Lusignan, Etienne, Chapter 23, 'Les droits que les Comtes de Laval pretendent au Royaume de Hierusalem', in Les droicts, autoritez et prérogatives que prétendent au Royaume de Hierusalem, les Princes et Seigneurs Spirituels et Temporels (Paris, Guillaume le Noir, 1586) [British Library, 606.e.22 (2)].

18 Buisson, L. and Servin, L., Arrest d'appoincté au conseil donné en la chambre de l'édict le 19 juillet 1606 en la cause d'entre dame Anne d'Allegre ... et dame Charlotte de Nassau princesse en Aurange (s.1., 1606) [Author's collection].

19 Quereau, V., Epitome ou brief recueil de l'histoire universelle, depuis la création du monde, selon l'ordre des temps, jusques à l'an présent 1611 (Paris, François Huby, 1611) [BnF, 16 G 7163] and Du Chesne, A., Histoire généalogique de la maison de Montmorency et de la maison de Laval (ed. Hozier, S. Cramoisy, Paris, 1629) [BnF Rés. Lm3 671]. 
burnt with all the other papers during the royalist rebellion. ${ }^{20}$ Luckily, however, a copy of the analytical volume survived and is now in the Archives Nationales in Paris. ${ }^{21}$ This work is by far the most interesting text on the counts de Laval and is full of lengthy quotes from the original documents. ${ }^{22}$

Thereafter, the Lavals attracted scarcely any attention until the start of the twentieth century. Julien Le Clerc du Flécheray offered a short historical overview of Laval at the end of the seventeenth century, whilst Charles Maucourt de Bourjolly wrote a history of the house of Laval that in the words of one severe critic often relied on 'des fables indignes d'un historien sérieux'. ${ }^{23}$ But that did not stop future authors from peddling these stories over a century later. ${ }^{24}$ Others such as Louis Dubois, the historian of Vitré, show the confusion that reigned with regard to the counts de Laval. The fact that Couanier de Launier's book on Laval which dates from 1894 is still considered to be the best book on the subject is indicative of this lack of serious study. ${ }^{25}$

Since this time, the only work of importance has been the archival work by André Bertrand de Broussillon who at the start of the twentieth century attempted to gather together all the documents existing on the house of Laval. ${ }^{26}$ The transcriptions he made are commendably exact and taken together form a priceless ensemble, but his work was heavily based on the Parisian collections. The holdings of relevant provincial archives and libraries were not examined in the same systematic manner. Furthermore, Broussillon did not include printed material and it is also the case that many documents have only come to light since he wrote - such as the fabulous collection of Le Moyne de La Borderie. Thus despite the exemplary work done by

20 Duchemin de Villiers, J.-A., Essais historiques sur la ville et le pays de Laval (Laval, 1843 ) describes the fate of these volumes.

21 AN MM 746. See also Bertrand de Broussillon, L.-A., 'Découverte d'un volume de Le Blanc de La Vignole aux Archives Nationales'. The chapter entitled 'Chronologie historique des sires, puis comtes, de Laval' in L'Art de vérifier les dates (Paris, 1784) II, 864-875 is taken from Le Blanc de La Vignole's manuscript (see p. 864).

22 Le Blanc de La Vignole also wrote a commentary on the customs of Maine which was held in high regard (Laval BM Ms. 2). The exactitude of his transcriptions is proven by crossreferencing documents for which other copies have survived.

23 Le Clerc du Flécheray, J., Description du comté de Laval, son histoire, ses mours et ses habitants (ed. Godbert, Laval, 1860) the original was written circa 1688. Bertrand de Broussillon in his edition of Maucourt de Bourjolly, C., Mémoire chronologique des seigneurs fondateurs, du château et de la ville de Laval (eds Le Fizelier, J. and Bertrand de Broussillon, L.-A., Laval, 1886) commented that 'son oeuvre n'a donc aucun droit à une confiance absolue' (I, xiii).

24 See Foucault, M., Les seigneurs de Laval (Laval, 1875).

25 Dubois, L., Vitré. Essai sur l'histoire de la ville et de ses seigneurs jusqu'à la révolution de 1789 (Paris, 1839). Guy XIV would have died in 1436, Guy XV in 1486, whilst Guy XVI would have been count from 1486 to 1531. Couanier de Launay, M.E.L., Histoire de Laval (Second edition, Laval, 1894).

26 Bertrand de Broussillon, L.-A., La maison de Laval, 1020-1605, étude historique accompagnée du cartulaire de Laval et de Vitré (Paris, 1895-1903). 
Bertrand de Broussillon, one can now triple the number of documents concerning the house of Laval available to scholars of the fifteenth and sixteenth centuries.

The ideas of lineage and heritage were fundamental to noble families. We will therefore begin this book by sketching the evolution of the family from the end of the tenth century to the beginning of the fifteenth. It will then be possible to analyse the rise of the barons and then counts de Laval from the final decades of the Hundred Years War to the start of the sixteenth century. We will see how during this period Guy XIV (1414-1486) and Guy XV (1486-1501) strengthened and widened their affinity, developing their households and the administrative structures of their territories. This will lead to a detailed analysis of the constituent parts of the clientage network where we will examine the role played by family, the court and those involved in the administration of their estates.

The affinity of the counts of Laval reached its apogee in the first half of the sixteenth century. This golden age was particularly notable for the illustrious court maintained by the counts and the impressive careers of some of the Lavals' clients. This period contrasts starkly with the more difficult times of the Wars of Religion where we shall see the effects of the conversion of the Lavals on their affinity. The final part of this book will retrace the evolution of the affinity through the prism of a unique relationship. The analysis of the complex rivalry between the houses of Laval and Rohan demonstrates in a quite extraordinary way the connections between the issues of precedence, status and clientage even at the very end of the sixteenth century. This dispute, which set against each other the two leading Protestant families of western France, offers a very particular demonstration of the enduring strength of noble values in Early Modern society. 
$\because$ Taylor \& Francis

Taylor \& Francis Group

http://taylorandfrancis.com 


\section{Bibliography}

\section{Manuscripts}

Angers: Bibliothèque Municipale

Ms.710: Document on the chapel of Les Rivettes, 15th-16th century

Angers: Archives Départementales du Maine-et-Loire

E 3024: Letters of Guy XIX for the chapel Ste Marthe, 1582

H 1: Papal bull naming the abbot of Saint-Aubin, 1463/4

1 J 1907: Documents on Montreuil-Bellay, 1490

1 J 2947: Refusal of homage for Baugé, 1499

Angers: Archives Municipales

GG1 36 (St Mathurin): 'Pappier des registres des trespassez', 1585

Laval: Archives Départementales de la Mayenne

E 183: Notarial act by Michel Freuslon, 1567

$1 \mathrm{~J} 22$ to $1 \mathrm{~J} 586$ : Documents on the family of Laval 15th-16th centuries

14 J 396: Letters of Guy XVII for the family of Brée, 1542

15 J 29: Register on the succession of the house of Laval, 1608

$16 \mathrm{~J} 34$ to $16 \mathrm{~J}$ 105: Documents on the family of Laval 15th-16th centuries

109 J 55: Accounts for La Gravelle, 1535-1555

$126 \mathrm{~J} 6$ to $126 \mathrm{~J} 80$ : Documents on the family of Laval 15th-16th centuries

127 J 62: Agreement on Jeanne de Laval's inheritance, 1498/9

$1 \mathrm{mi} 141$ (386): Letters of Jean Herault officer in the county of Laval, 1546

$1 \mathrm{mi} \mathrm{144/7}$ fo. 299: Letters by Guy XV for La Chapelle, 1490

$1 \mathrm{mi}$ 146: Accounts for Laval, 1475-1478

\section{Laval: Bibliothèque municipale}

Ms. 2: Commentary on the customs of Maine by Le Blanc de La Vignole, 17th century

Ms. 209: Payment of André de Laval-Lohéac's ransom, 1428

Ms. 277: Accounts for Saint-Ouen, 1517-1518

Ms. 341: 'Depositions d'aucuns tesmoins es trois enquestes du seigneur comte de Laval' 1476-1478

Ms. 342: Marriage contracts of the house of Laval, 15th century

London: National Archives (Public Record Office)

C 47/28/7: Letters of Henry VI for Guy XIV, 1446 
SP 68/3: State papers foreign, Edward VI, 1547 to 1553

SP 70/144 to 147: State papers foreign, Elizabeth I, 1558 to 1577

SP 78/3 to 20: State papers foreign, France, reign of Elizabeth I

SP 83/18: State Papers Foreign, Holland and Flanders 1583

SP 101/9: State Papers Foreign, Newsletters, 1579

SP 103/33: State Papers Foreign, Treaty Papers, reign of Elizabeth I

Le Mans: Archives Départementales de la Sarthe

E 309: Letters by Guy XV for Catherine d'Alençon, 1481

5 F 342: Guy XIX to La Roche Jagu, 1578

70 J 18: Letters by Guy XVI, 1514

Nantes: Archives Départementales de Loire Atlantique

B 3 to B 5: Letters by the dukes of Brittany, 15th century

B 1259 to B 2178: Homages to the duke for lands in Brittany, 15th-16th centuries

C 414: Registers of the Estates of Brittany, 1576-1578

E 76: Bull naming the bishop of St Brieuc, 1471/2

E 122: Archives of the dukes of Brittany, 1443-1471

E 131: Letters on the trial of Jean d'Espinay, 1461

E 191-2: Documents on the trial of Pierre de Rohan, 1494-1505

E 439: Gift to Guy Eder by Guy XIV, 1430

\section{Nantes: Bibliothèque Municipale}

Ms. 1687: Papers for Yolande de Laval and Alain de Rohan, 1442

Ms. 1874: Papers of Dom Morice on the house of Rohan

Paris: Archives Nationales

AA 55 no. 1516: Letters of Guy XIX, 1577

AA 60: Memoir to prevent the elevation of the land of Espinay, 1576

1 AP 587 to 590, 1 AP 617, 1 AP 1584, 1 AP 1759 to 1763: 'Chartier de Thouars', 15 th- 17 th centuries

273 AP 145: Sale of a house in Paris by Guy XVII, 1545

380 AP 2: Marriage contract of Yolande de Laval and Guillaume de Harcourt, 1454

JJ 254 fo.54: Legitimisation of François de Laval, March 1539/40

JJ 257/1: Elevation of Nesle by Francis I, January 1545/6

MC XIX 106 and 175-179: Notarial records, 16th century

MC CXXII 129: Notarial records, 16th century

MM 746: Le Blanc de la Vignole, J., 'Histoire de la maison de Laval'

P 1334/5: Homage for Candé, 1450

P 1365/1: Agreement between Guy XVI and Catherine d'Alençon, 1501

T 1051/17 to T 1051/19: Papers of the émigré La Trémoïlle, 15th-16th centuries

$\mathrm{X} / 1$ a 1595: Registers of the Parlement for 1560

$\mathrm{X} / 1 \mathrm{a} 4833$ to 4839: Registers of the Parlement for 1491 to 1497

$\mathrm{X} / 1 \mathrm{a} 4930$ Registers of the Parlement for 1547 
X/1a 8608: Letters registered by the Paris Parlement, 14812

Y 91: Gift by Guy XVII for the duc de Guise, 1546

Y 95: Payment by Guy XVIII for de Thou, 1549

\section{Paris: Bibliothèque Nationale}

500 Colbert 16 and 494: Documents on the house of Laval, 1585

Clairambault 64: Guy XVI's wages, 1529

Dupuy 261: Guy XVI to Francis I on Brittany, [1523]

Dupuy 424: Letters by Tilenus to Guy XX, 1604-1605

Fr. 2707: Letters by Guy XVI and Charlotte d'Aragon to Anne de Bretagne, [15011505]

Fr. 2710: Documents on Brittany and the house of Laval, 1430-1450

Fr. 3039: Letters to Anne de Montmorency, 16th century

Fr. 3212: Letters to and from Menault de Martory, 1530-1550

Fr. 3321: Letters by Henry III, 1579

Fr. 3807: Elevation of Laval: 17 July 1429

Fr. 5121: Letters for Guy XVII, 1535-1544

Fr. 5127: Royal letters for the Lavals, 16th century

Fr. 5502: Royal letters for the Lavals, 16th century

Fr. 6637: Lettres to Anne de Montmorency, 16th century

Fr. 7853: Register of the queen's household, 1530-1546

Fr. 8269: Documents on Brittany (15th-16th centuries)

Fr. 11450: Documents on the house of Laval (17th century copies)

Fr. 15537: Memoir by Antoine de Chabannes and the Dauphin's request, 14461450

Fr. 11542: Ducal payments, 1431

Fr. 19018: Histoire de Florence translated by Louveau, ca. 1585

Fr. 19819: Statutes for the order of St Michel, 1469

Fr. 20285: Copies of documents on the houses of Thouars, Laval and Amboise

Fr. 20461: Documents on the rivalry Coligny-Guise, (16th century)

Fr. 20502: Letters to Anne de Montmorency, 16th century

Fr. 20553 fo.146: Guyonne to François de Lorraine, 27 January [1548]

Fr. 21450: Accounts for Francis I's household, 16th century

Fr. 22310 to Fr. 22342: Documents on Brittany and the house of Laval

Fr. 26281 no. 165: Company of André de Laval-Lohéac, 1469

Fr. 27552: Letters on the house of Espinay, 16th century

Fr. 28152 to Fr. 28154: Documents on the house of Laval

Fr. 32865 to Fr. 32866: Registers of the order of St Michel

NAF 74: Description of Anne de Bretagne's funeral, 1513/4

NAF 1232: Guy XV to Charles VIII, 1489

NAF 1723: Jean de Gennes's journal (16th century)

NAF 8608: Company of André de Laval-Lohéac, 1470

Lat. 920: Louis de Laval-Châtillon's book of hours

Lat. 7809: Publitius, J., 'Panegyricus domus Lavallensis' (15th century) 
Lat. 18401: Copy of the letters given by Louis XII, 1503

Rennes: Archives Départementales d'Ille-et-Vilaine

1 BA 1 to 1 BA 8: Registers of Rennes Parlement, 16th century

C 2644: Registers of the meeting of the Estates of Brittany, 1595

$1 \mathrm{E}$ 1: 'Trésor des ducs de Bretagne', 15th century

3 E 377: Calvinist consistory records for Vitré, 1560-1600

2 EA 1: Gift by françoise de Dinan for the house of Acigné, 1489/90

2 EE 4: Documents on the minority of Guy III d'Espinay, 1524

2 EL 77 to 2 EL 78: Documents on the house of Laval, 1431-1633

2 ER 183: Marriage contract of Catherine de Laval and Claude I de Rieux, 1518

1 F 222: Partial copy of Legeay's manuscript on the Espinays

$1 \mathrm{~F} 912$ to $1 \mathrm{~F} 914$ : Documents on the house of Laval, 15th-16th centuries

1 F 917 to 1 F 919: Accounts for Laval lands, 15th-16th centuries

$1 \mathrm{~F}$ 1122: 'Mémoire des nobles de Bretagne', 1529

$1 \mathrm{~F} 1200$ to $1 \mathrm{~F}$ 1201: Accounts for the town of Vitré: 15th-16th centuries

1 F 1228 to 1 F 1234: Documents on the house of Laval, 15th-16th centuries

1 F 1252 to 1 F 1253: Documents on Quintin, 16th century

1 F 1257: Request sent to parlement de Rennes on Quintin, 1590

$1 \mathrm{~F} 1282$ to $1 \mathrm{~F}$ 1283: Documents on Beauregard and Belle-Isle, 16th century

$1 \mathrm{~F}$ 1287: Documents on Kergorlay and Laz, 16th century

$1 \mathrm{~F} 1302$ to $1 \mathrm{~F}$ 1307: Documents on the county of Quintin, 1507-1786

$1 \mathrm{~F} 1328$ to $1 \mathrm{~F} 1371$ : Accounts for the plain and town of Quintin, 1503-1595

1 F 1398 to 1 F 1411: Accounts for Bothoa, 1508-1579

$1 \mathrm{~F} 1424$ to $1 \mathrm{~F}$ 1452: Accounts for the forest of Quintin, 1507-1582

1 F 1481 to 1 F 1488: Accounts for Toulmen, 1506-1522

1 F 1495 to 1 F 1496: Accounts for Belle-Isle et Beaufou, 1508-1522

1 F 1510 to 1 F 1514: Accounts for du Perrier, 1506-1521

1 F 1530: Documents on Châtillon-en-Vendelais, 15th-16th centuries

$1 \mathrm{~F} 1532$ to $1 \mathrm{~F}$ 1550: Documents on various Laval lands, 15th-16th centuries

1 F 1552: Documents on the house of Laval, 1522-1582

5 J 168: Legeay, J. 'Au lecteur de bonne volonté sur les louanges des grandes alliances, antiquités, singularités, de l'illustre florissante et très heureuse maison d'Espinay'

\section{Rennes: Archives Municipales}

Liasse 11: Accounts for the town of Rennes, 15th-16th centuries

Liasse 239 to 240: Accounts for the town of Rennes 1542-1587

Liasse 343: Ban on Protestantism in Rennes, 1563

Rouen: Archives Départementales de la Seine-Maritime

1 ER 482: Documents on Harcourt, 1584

G 1169: Papers gathered after the death of Gilles de Laval, bishop of Sées, 14881507 
G 3717: Letters by Charles de Lorraine on his inheritance, 1588

Saint-Brieuc: Archives Départementales des Côtes d'Armor

E 1184: 'Mémoire historique des sires de Bellisle et Baufou 1404-1760'

2 E 427: Accounts for Montfort-sur-Meu, 1501-1502

114 J 1: La Rochepot to Danille, 1532

Strasbourg: Archives Municipales

XXI 1580: Town council deliberations, 1580

Thévalles: Archives privées du Château de Thévalles

Carton 190: Letters by the Lavals, 1547

Vannes: Archives Départementales du Morbihan

G 309 to G 310: Documents on the parish of Rochefort, 1587-1598

Vitré: Archives Municipales

DD 7: Accounts for the construction of a new tower in Vitré, 1419-1420

Ms. 4: Register on Guy XX's inheritance, 1608

\section{Printed sources}

Apulée, L., De l'âne doré (Lyon, Temporel, 1553)

Argentré, B. d', Histoire de Bretaigne, des roys, ducs, comtes et princes d'icelle (Rennes, J. Du Clos, 1582)

Arioste, Aristote, du Monde. Philon, du Monde. Songe de Scipion. Le tout mis nouvellement de Grec en François (Pierre de Tours, Lyon, 1542)

Aubigné A. d', Histoire universelle (ed. Ruble,A. de, Paris, 1886-1925)

Aubigné A. d', Oeuvres complètes (ed. Réaume and Caussade, Paris, 1873)

Auton, J., Chroniques de Louis XII (ed. Maulde-la-Clavière, R. de, Paris, 1889)

Basin, T., Apologie ou plaidoyer pour moi-même (ed. Samaran, C., Paris, 1974)

Basin, T., Histoire de Louis XI (ed. Samaran, C., Paris, 1963-1972)

Berger de Xivrey, M. (ed.), Recueil de lettres missives de Henri IV (Paris, 18431876)

Bertrand de Broussillon, L.-A. (ed.), La maison de Laval, 1020-1605, étude historique accompagnée du cartulaire de Laval et de Vitré (Paris, 1895-1903)

Bertrand de Broussillon, L.-A. (ed.), 'Lettre de Henri III à Lancelot de Brée' Province du Maine, (1903) 24-25

Bertrand de Broussillon, L.-A. (ed.) 'Donation de Guyonne de Laval aux cordeliers de Bodelio’ Province du Maine, (1905) 248-250

Béthune, M. de (duc de Sully), Les Oeconomies Royales (eds Buisseret, D. and Barbiche, B., Paris, 1970) 
Bèze, T. de, Histoire Ecclésiastique des églises réformées au royaume de France en laquelle est descrite au vray la renaissance et accroissement d'icelles depuis l'an M. D. XXI. jusques en l'année M. D. LXIII. (Jean Remy, Geneva, 1580)

Blanchard, R. (ed.), Lettres et mandements de Jean V, duc de Bretagne de 1402 à 1444 (Nantes, 1889-1895)

Blondel, D., De regni Napolitani jure, pro Tremollio duce (Paris, 1648)

Bouchart, A., Grandes Croniques de Bretaigne (ed. Auger, M.-L. and Jeanneau, G., Paris, 1986)

Brant, S., The shyppe of fooles (Wynkyn de Worde, London, 1509)

Bref receuil de l'assassinat commis en la personne du très illustre prince, Monseigneur le Prince d'Orange, conte de Nassau, marquis de la Vere etc par Jean Jauregui Espaignol (Christophe Plantin, Anvers, 1582)

Brantôme, Oeuvres complètes (ed. Bouchon, J., Paris, 1838)

Buisson, L. and Servin, L., Arrest d'appoincté au conseil donné en la chambre de l'édict le 19 juillet 1606 en la cause d'entre dame Anne d'Allegre ... et dame Charlotte de Nassau princesse en Aurange (s.1., 1606)

Calendar of Letters, Despatches and State Papers relating to the negotiations between England and Spain, preserved at the Archives at Simancas and elsewhere. Henry VIII (London, 1873-1899)

Calendar of Letters, Despatches and State Papers relating to the negotiations between England and Spain, preserved at the Archives at Simancas and elsewhere. Edward VI (London, 1904-1916)

Calendar of State Papers Foreign Series of the Reign of Henry VIII 1509-1546 (eds Brewer, J.S. et al., London, 1862-1932)

Calendars of State Papers. Foreign Series of the Reign of Elizabeth (1558-1589) (eds Stevenson, J. et al., London, 1863-1950)

Carloix, V., Mémoires de la vie de François de Scepeaux, sire de Vielleville et comte de Duretal, maréchal de France (Paris, 1757)

Catalogue des actes de François I (eds Marichal, P. et al., Paris, 1887-1910)

Catalogue des actes de François II (ed. Martel, M.-J., Paris, 1991)

Catalogue des actes de Henri II (eds Baudouin-Matuszek, M.-N. et al. Paris, 19791990)

Catalogue des trèsillustres Ducz et Connestables de France depuis le Roy Clotaire premier du nom, jusques à trèspuissant, trèsmagnanime et trèsvictorieux Roy de France, Henry deuxième (Paris, Michel de Vascosan, 1555)

Chappuys, C., Discours de la court présentée au Roy (Paris, André Roffet, 1543)

Chartier, A., 'Le Breviaire des nobles' in Poèmes (ed. Laidlaw, J., Paris, 1988)

Chartier, J., Chronique de Charles VII (ed. Vallet de Viriville, Paris, 1858)

Chastelain, G., Chronique (ed. Lettenhove, K. de, Bruxelles, 1863-1866)

Choque, P., Récit des funérailles d'Anne de Bretagne précédé d'une complainte sur la mort de cette princesse et de sa généalogie, le tout composé par Bretaigne, son hérault d'armes (Merlet, C. and Gombert, M. de (eds), Geneva, 1970)

'Chronologie historique des sires, puis comtes, de Laval' in Art de vérifier les dates (Paris, 1784) II, 864-875 
Clouard, E. (ed.), 'Deux bourgeois de Vitré, journal inédit' Revue de Bretagne, (1914) 197-237

Correspondance des nonces en France, Acta Nuntiaturae Galliae. Anselmo Dandino (1578-1581) (ed. Cloulas, I., Paris, 1970)

Corte verclaringe ghedaen by Borgemeesteren, Schepenen ende Raedt der stadt van Antwerpen, nopende den aenslach teghen de selue stadt aengericht den XVII. deser maent Januarij M. D. LXXXIII. (Christophe Plantin, Anvers, 1583)

Couanier de Launay, M.E.L. (ed.), 'Aveu du comté de Laval à René duc d'Anjou, roi de Sicile, comte du Maine, 1444' Bulletin de la Commission Historique et Archéologique de la Mayenne, 2 (1889) 503-530, and 3 (1890) 45-70

Cuisat, D. (ed.), Lettres du cardinal Charles de Lorraine (1525-1574) (Geneva, 1998)

Dampierre, sieur de, Lettre escripte par le sieur de Dampierre, gentilhomme suyvant M. le Duc de Rouanois, grand Escuyer de France, à Madame la Duchesse sa femme par laquelle il se voit la façon dont ledict grand Escuyer a esté pillé, pris et emmené de sa maison, par ceux qui portent les armes contre le Roy (Paris, Robert Estienne, 1568)

La division du Monde contenant la déclaration des provinces et régions d'Asie, Europe, et Aphricque (Alain Lotrian, Paris, 1544)

De Lusignan, Etienne, Chapter 23, 'Les droits que les Comtes de Laval pretendant au Royaume de Hierusalem' in Les droicts, autoritez et prérogatives que prétendent au Royaume de Hierusalem, les Princes et Seigneurs Spirituels et Temporels (Paris, Guillaume le Noir, 1586) [British Library, 606.e.22(2)]

Dorleans, R., Les observations de diverses choses remarquées sur l'estat, couronne et peuple de France, tant ancien que moderne (Vannes, Jean Bourrelier, 1597)

Du Bellay, M. and du Bellay, G., Mémoires (ed. Bourrilly, V.-L. and Vindry, F., Paris, 1908)

Du Bois-Gelin, C., Traité des droits royaux de bris et de brefs ou seaux leurs causes, effets, origine et autres singularitez concernantes ceste matière (Dinan, Julien Aubinière, 1595)

Du Bouchet, J., Preuves de l'histoire de l'illustre maison de Coligny, tirées des chartes de diverses églises et abbayes, et de plusieurs autres titres, mémoires, chroniques et histoires dignes de foy (Jean du Puys, Paris, 1662)

Du Chesne, A., Histoire généalogique de la maison de Montmorency et de la maison de Laval (ed. Hozier, S. Cramoisy, Paris, 1629)

Du Fail, N., Les plus solemnels arrests et reglemens donnez au parlement de Bretagne (Mareschal, Nantes, 1715)

Du Fail, N., Contes et discours d'Eutrapel (ed. Hippeau, C., Paris, 1875)

Du Haillan, Bernard de Girard, De l'estat et succez des affaires de France ... contenant sommairement l'histoire des Roys de France, et les choses plus remarquables par eux instituées pour l'ornement et grandeur de leur Royaume (Pierre L'Huillier, Paris, 1572)

Du Paz, A., Histoire généalogique de plusieurs maisons illustres de Bretagne (Paris, Nicolas Buon, 1619) 
Duplessis-Mornay, C.A., Mémoires et Correspondance (ed. La Fontenelle de Vaudoré, A.-D. de, Geneva, 1969)

Escouchy, M. d', Chronique (ed. du Fresne de Beaucourt, G., Paris, 1864)

Etasse, M., 'Documents inédits concernant la baronnie de Vitré: Droits et devoirs, usages, rentes, redevances, etc.' Bulletin et Mémoires de la Société d'Archéologie du département d'Ille-et-Vilaine, 39 (1910) 1-125 and 42 (1913) 97-142

Falle, P., Caesarea or an account of Jersey (London, 1735)

Gachard, L. (ed), Correspondance de Philippe II sur les affaires des Pays-Bas (Bruxelles, 1848)

Gesland, J., Addition à la Chronique de Le Baud (ed. D’Hozier, Paris, 1638)

Gilles, N. and Sauvage, D., Annales et croniques de France depuis la destruction de Troyes jusques au temps du Roy Loys onziéme (Paris, Jean de Roigny, 1553)

Godbert, M. (ed.), Documents relatifs à l'histoire du Comté de Laval (Laval, 1860)

Godefroy, T., Le cérémonial françois (S. Cramoisy, Paris, 1649)

Goulart, S., Le second recueil contenant l'histoire des choses plus mémorables advenues sous la ligue. Avec une exhortation notable aux rois et estats chrestiens (s.1., 1589)

Gouyon, C., Mémoires de Charles Gouyon, baron de la Moussaye (1553-1587) (ed. Vallée, G. and Parfouru, P., Paris, 1901)

Les grandes croniques de Bretaigne, parlans des très preux, nobles et très belliqueux roys, ducz, princes, barons et aultres gens nobles (Caen, 1532)

Hamblin, V.L. (ed.), The Fifteenth Century French "Mistere du Siege d'Orleans"; an Annotated Edition (Thesis, Arizona, 1984)

Henri III, Edict de pacification faict par le Roy pour mettre fin aux troubles de son royaume (Fédéric Morel, Paris, 1577)

Hérodien, L'Histoire de Herodian autheur Grecq des Empereurs Romains depuis Marcus, tournée de grecq en latin par Ange Politian, et de latin en francoys par Jehan Collin (Jean Foucher, Paris, 1541)

Hotman, F., C. Julii Caesaris de Bello Gallico Commentarii, (Barthélemy Vincent, Lyon, 1573)

Hotman, F., La vie de messire Gaspar de Colligny, Admiral de France (ed. Telle, E.-V., Geneva, 1987)

Journal d'un bourgeois de Paris sous François Ier (1515-1536) (ed. Lalanne, L., Paris, 1854)

La Boetie, E. de, Discours de la servitude volontaire (ed. Bayard, F., Paris, 1992)

La Croix du Maine, Premier volume de la bibliothèque du sieur de la Croix-duMaine, qui est un catalogue général de toutes sortes d'autheurs, qui ont escrit en François depuis cinq cents ans et plus (Abel L'Angelier, Paris, 1584)

La Ferrière, H. de and Baguenault de Puchesse, G., (eds) Lettres de Catherine de Médicis (Paris, 1909)

La Loupe, V. de, Origine des dignitez, magistratz, office et estats du royaume de France (Benoist Rigaud, Lyon, 1572)

La Trémoïlle, L. de (ed.), Chartrier de Thouars, documents historiques et généalogiques (Paris, 1877) 
La Trémoïlle, L. de (ed.), Les La Trémoïlle pendant cinq siècles (Nantes, 18901896)

La Trémoïlle, L. de (ed.), Correspondance de Charles VIII et de ses conseillers avec Louis II de La Trémoïlle pendant la guerre de Bretagne en 1488 (Paris, 1875)

Le Baud, P., Chronique de la maison de Vitré (ed. Hozier, Gervais Alliot, Paris, 1638)

Le Baud, P., Histoire de Bretagne (ed. Hozier, Gervais Alliot, Paris, 1638)

Le Bouvier, G., Les chroniques du roi Charles VII (ed. Courteault, H. and Celier, L., Paris, 1979)

Le Clerc du Flécheray, J., Description du comté de Laval, son histoire, ses mours et ses habitants (ed. Godbert, Laval, 1860)

Le Doyen, G., Annalles et Chronicques du pais de Laval et parties circonvoisines (ed. Morin de La Beauluère, L.-J., Laval, 1859)

Lejeune, A., Le conseil ducal de Bretagne au début du principat de François II (1459-1463) (Thesis de l'Ecole des Chartes, Paris, 1989)

Lesrat, G. de, Arrests notables donnez en la court de Parlement de Bretagne et prononcez en robbe rouge (Jérôme de Marnef, Paris, 1588)

L'Estoile, P. de, Registre-Journal du règne de Henri III (ed. Lazard et Schrenck, Geneva, 1997)

L'Estoile, P. de, Journal de l'Estoile pour le règne d'Henri IV (ed. Martin, G., Paris, 1958)

Le Maistre, R., Original des troubles de ce temps. Discourant briefvement des princes plus illustres de la très ancienne et très illustre famille de Luxembourg et de leurs alliances généalogiques (Nicolas des Marestz and François Faverye, Nantes, 1592)

Le Maistre, R., Brief discours de la vie et mort des princes très illustres et très puissans, Charles et Sébastien de Luxembourg (Nicolas des Marestz and François Faverye, Nantes, 1592)

Le Noir, P., Histoire ecclésiastique de Bretagne depuis la réformation jusqu'à l'édit de Nantes (ed. Vaurigaud, B., Paris, 1851)

Lettres de confirmation des privilèges du Comté et Pairie de Laval, du mois de Fevrier 1644, avec l'Arrest de verification d'icelles du premier Septembre 1657 (s.l., s.d.)

Lettres d'un François, sur certain discours faict naguères, pour la préséance du Roy d'Hespagne (s.1., 1587)

L'Hospital, M. de, Discours pour la majorité de Charles IX et trois autres discours (Descimon, R. (ed), Paris, 1993)

Lobineau, G.-A., Histoire de la Bretagne (Paris, 1707)

La magnificque et triumphante entrée du trèsillustre et sacré Empereur Charles (s.l., s.n., [1540])

Marchegay, P. (ed.), Lettres missives originales du XVe siècle (Niort, 1873)

Marchegay, P. (ed.), Lettres missives originales du XVIe siècle (Niort, 1881) 
Marion, S., Plaidoyez de Maistre Simon Marion, baron de Druy, cy devant advocat en Parlement et de présent conseiller du Roy en son conseil d'estat et son advocat général (Michel Sonnius, Paris, 1598)

Maucourt de Bourjolly, C., Mémoire chronologique des seigneurs fondateurs, du château et de la ville de Laval (eds Le Fizelier, J. and Bertrand de Broussillon, L.-A., Laval, 1886)

Merlin, J., Diaire ou journal du ministre Merlin (Geneva, 1855)

Merlin, P., XXVI Sermons sur le livre d'Ester (La Rochelle, Jérôme Haultin, 1591)

Merlin, P., Sermons sur le livre d'Ester ... deuxiesme édition augmentée d'un ample argument sur toute l'histoire d'Ester (Geneva, François Le Preux, 1593)

Meschinot, J., Les lunettes des princes (ed. Martineau-Genieys, C., Geneva, 1972)

Mithou, A., L'ordre funèbre et pompe pitoyable tenue à l'enterrement de M le comte de Laval (Angers, 1531)

Monjoye, G., L'ordre des joustes faictes à Paris à l'entrée de la royne (s.l., s.n. [1514])

Morice, H. Dom (ed.), Mémoires pour servir de preuves à l'histoire ecclésiastique et civile de la Bretagne (Paris, 1742-1746)

Mornable, A. de, Livre second contenant XVII pseaulmes de David, traduictz de Latin en François par Clément Marot et naguères mis en musique en quatre pièces séparées (Pierre Attaignant, Paris, 1546)

Moulin, C., Premier tome des coustumes généralles et particulières du royaume de France et des Gaulles (Paris, Jacques du Puys, 1581)

Müller, P. and Diegerick, A., Documents concernant les relations entre le duc d'Anjou et les Pays-Bas (1576-1583) (Utrecht, 1889-1899)

Ordonnances des rois de France. Règne de François I (Paris, 1916)

Paré, A., Oeuvres complètes (ed. Malgaigne, J.-F., Paris, 1840-1841)

Paris, Parlement de, Arrest de la Court de Parlement, par lequel est enjoinct à toutes personnes soient Ecclesiastiques, Gentilz-hommes: où autres, possedans lieux et maisons fortes, de y mettre Capitaines et Soldats, (de la Religion Catholique, Apostolique and Romaine,) en nombre suffisant, pour la garde d'icelles (Paris, Guillaume de Nyverd, 1569)

Paris-Jallobert, P., Journal historique de Vitré ou documents et notes pour servir à l'histoire de cette ville (Vitré, 1880)

Pélicier, P. (ed.), Lettres missives de Charles VIII (Paris, 1898-1905)

Potter, P. (ed.), Un homme de guerre au temps de la Renaissance: La vie et les lettres d'Oudart du Biez, Maréchal de France, Gouverneur de Boulogne et de Picardie (vers 1475-1553) (Arras, 2001)

Pour messire Henry de la Trimoüille, duc et pair de France, Comte de Laval etc, and demandeur en Requeste du 20 Novembre 1625 ... Contre Maistre Pierre Marest, Juge des Exempts (s.1., s.d.)

Quereau, V., Epitome ou brief recueil de l'histoire universelle, depuis la création du monde, selon l'ordre des temps, jusques à l'an présent 1611 (Paris, François Huby, 1611) 
Remonstrance aux habitans de la ville de Nantes par un des citoyens d'icelle: par où se void les pratiques et menées dont a usé le duc de Mercoeur pour usurper le duché de Bretaigne (Michel Logeroys, Rennes, 1590)

Richard, J.-M. (ed.), 'Deux documents relatives au château de Laval, 1542 et 1631' Bulletin de la Commission Historique et Archéologique de la Mayenne, 16 (1900) 422-433

Rivault de Fleurance, D., Les Estats, esquels il est discouru du prince, du noble et du tiers estat (Lyon, 1596)

Robert, C. (ed.), 'Privilèges accordés à Raoul, seigneur du Boschet, par Jehanne de Laval, douairière de Vitré' Bulletin et Mémoires de la Société d'Archéologie du département d'Ille-et-Vilaine, 22 (1893) 287-290

Rosay, J. de, Relief de l'âme pécheresse (Jean André, Paris, 1542)

Rymer, T. (ed.), Foedera, conventiones et literae (London, 1704-1735)

State Papers, published under the Authority of His Majesty's Commission: King Henry the Eighth (London, 1830-1852)

Strada, J. de, Epitome du thrésor des antiquitez (Lyon, Strada et Gurin, 1553)

Thou, J.-A. de, Histoire Universelle (London, 1734)

Titres du Comté de Laval et de ses Privileges (Paris, Pierre Des-Hayes, 1667)

Tuetey, A. et al. (eds), Registres des délibérations du Bureau de la Ville de Paris (1499-1624) (Paris, 1883-1953)

Vaesen, J. and Charavay, E. (eds), Lettres de Louis XI (Paris, 1883-1909)

Wood, M. (ed.), Foreign Correspondence with Marie de Lorraine Queen of Scotland from the Originals in the Balcarres Papers (Edinbrugh, 1923-1925)

\section{Dictionaries and inventories}

Angot, A., Dictionnaire historique, topographique et biographique de la Mayenne (Laval, 1903-1910)

Anselme de Sainte Marie, Histoire généalogique et chronologique de la maison royale de France, des pairs, grands officiers de la Couronne et de la maison du roi et des anciens barons du royaume (3rd edition, Paris, 1726-1735)

Chevalier, U., Répertoire des sources historiques du Moyen-Age. Topo-bibliographie (Paris, 1894-1899)

Chevalier, U., Répertoire des sources historiques du Moyen-Age. Bio-bibliographie (Paris, 1877-1886)

Dictionnaire de Biographie Française (Paris, 1933-)

Duquesne, J., Dictionnaire des Gouverneurs de Province sous l'ancien régime (novembre 1315-20 février 1791) (Paris, 2002)

Guillotin de Corson, A., Les grandes seigneuries de Haute Bretagne (Rennes, 18971899)

Guillotin de Corson, A., Les petites seigneuries de Haute Bretagne (Rennes, 18971907)

Haag, E. and Haag, E., La France protestante (Paris, 1888) 
Hoefer, F., Nouvelle biographie générale depuis les temps les plus reculés jusqu'à nos jours (Paris, 1855-1867)

Huguet, E., Dictionnaire de la langue française du seizième siècle (Paris, 19251967)

Jouanna, A. et al., Histoire et dictionnaire des guerres de religion (Paris, 1998)

La Chesnaye Desbois, A. de, Dictionnaire de la noblesse, contenant les généalogies, l'histoire et la chronologie des familles nobles de France (reprint Mendeln, 1970)

Laplace, A., Dictionnaire des fiefs, et autres droits seigneuriaux, utiles et honorifiques (Knapen, Paris, 1757)

Nassiet, M., 'Dictionnaire des feudataires des évêchés de Dol et Saint-Malo en 1480' Bulletin de l'Association Bretonne, (1990) 183-203, (1991) 265-296 and (1992) 221-251

Nassiet, M., 'Dictionnaire des feudataires de l'évêché de Saint-Brieuc en 1480' Société d'Emulation des.Côtes-d'Armor, 124 (1995) 7-86

Nassiet, M., 'Dictionnaire des feudataires de l'évêché de Tréguier en 1481' Société d'Emulation des Côtes-d'Armor, 127 (1998) 3-76

Ogée, J., Dictionnaire historique et géographique de la province de Bretagne (Rennes, 1845)

Paris-Jallobert, P., Anciens registres de l'église protestante de Vitré (Rennes, 1890)

Paris-Jallobert, P., Anciens registres paroissiaux de Bretagne (Rennes, 1894-1895)

Pottier de Courcy, P., Nobiliaire et armorial de Bretagne (Nantes, 1862)

Samaran, C., Archives de la maison de La Trémoille (Paris, 1928)

Sévegrand, G., 'La montre des gentilshommes de l'évêché de Rennes de 1541' Bulletin et Mémoires de la Société d'Archéologie du département d'Ille-et-Vilaine, 95 (1993) 73-127 and 96 (1994) 111-169

\section{Secondary sources}

Angot, A., Guy XX, sa conversion, son expédition contre les Turcs, sa mort (Laval, 1891)

Angot, A., 'L'assassinat de Criqueboeuf au château de Montjean' Société d'Archéologie et d'Histoire de la Mayenne, 28 (1912) 298-314

Angot, A., 'François Lesné, abbé de Sainte Catherine de Laval' Société d'Archéologie et d'Histoire de la Mayenne, 29 (1913) 30-35

Angot, A., Généalogies féodales mayennaises du XIe au XIIIe siècle (Laval, 1942)

Anis, A.-F., David Rivault et les autres précepteurs de Louis XIII (Laval, 1893)

Autrand, F., 'L'image de la noblesse en France à la fin du Moyen Age, tradition et nouveauté' Académie des inscriptions des belles-lettres (1979) 340-354

Babin, V., Espace et densité nobiliaires au XVIe et XVIIe siècles dans le Maine (MA thesis, Université du Maine, 1986)

Bartz, G., Das Stundenbuch des Guy de Laval (Cologne, 2004)

Baumgartner, F.J., Louis XII (New York, 1994) 
Béguin, K., Les princes de Condé. Rebelles, courtisans et mécènes dans la France du grand siècle (Seyssel, 1999)

Bertrand de Broussillon, L.-A. and Farcy, P. de, Sigillographie des comtes de Laval (Laval, 1888)

Beszard, L., 'Itinéraire de Guy de Laval en Autriche-Hongrie' Société d'Archéologie et d'Histoire de la Mayenne, 24 (1908) 129-140

Bitton, D., The French Nobility in Crisis, 1560-1640 (Stanford, 1969)

Bloch, M., La société féodale (Paris, 1968)

Bohuon, P., Sur les traces du caveau des comtes de Laval (Rapport de l'Inventaire du Patrimoine, Laval, 1998)

Bohuon, P. and Eraud, D., 'La collégiale Saint-Tugal de Laval' Société d'Archéologie et d'Histoire de la Mayenne, 22 (1999) 63-86

Boucher, J., Société et mentalités autour de Henri III (Thesis, Lille III, 1981)

Boucher, J., La Cour de Henri III (Rennes, 1986)

Bourquin, L., Noblesse seconde et pouvoir en Champagne aux XVIe et XVIIe siècles (Paris, 1994)

Bourquin, L., Les nobles, la ville et le roi. L'autorité nobiliaire en Anjou pendant les guerres de Religion (1560-1598) (Paris, 2001)

Bouton, A., Le Maine. Histoire économique et sociale: XIVe, XVe et XVIe siècles (Le Mans, 1970)

Bridge, J.S.C., A History of France from the Death of Louis XI (Oxford, 19211936)

Buat, Y., Successions, partages, donations, et communautés dans la province du Maine (Le Mans, 1996)

Busson, H., Charles d'Espinay, évêque de Dol, et son oeuvre poétique: 1531-1591 (Paris, 1923)

Carluer, J.-Y., Protestants et Bretons. La mémoire des hommes et des lieux (Paris, 1996)

Caron, M.-T., La noblesse dans le duché de Bourgogne 1315-1477 (Lille, 1987)

Caron, M.-T., Noblesse et pouvoir royal en France XIIIe-XVIe siècle (Paris, 1994)

Carroll, S., Noble Power during the French Wars of Religion: the Guise Affinity and the Catholic Cause in Normandy (Cambridge, 1998)

Cesbron, E., Jeanne d'Arc et le Bas-Maine (Laval, 1909)

Charbonnier, P., Une autre France. La seigneurie rurale en Basse-Auvergne du XIVe au XVIe siècle (Clermont-Ferrand, 1980)

Charier, C., Montreuil-Bellay à travers les âges (Saumur, 1913)

Chassin du Guerny, R., Etudes historiques sur l'organisation de la seigneurie de Quintin (Rennes, 1905)

Chauvin-Lechaptois, M., Les comptes de la châtellenie de Lamballe (1387-1482) (Rennes, 1977)

Chélini, J., Histoire religieuse de l'occident médiéval (Paris, 1968)

Choleau, J., Vitré la vie active d'une ville bretonne du XIIe siècle à la Révolution (Vitré, 1950-1954) 
Chollet, S., Politique territoriale des seigneurs de Laval sur la Marche BretagneMaine (11e-13e siècle) (MA thesis, Rennes, 2003)

Cintré, R., 'Activités économiques dans les marches de Bretagne aux XIVe et XVe siècles' Annales de Bretagne, 101 (1994) 7-36

Cintré, R., Les marches de Bretagne au moyen âge. Economie, guerre et société en pays de frontière (XIVe-XVe siècles) (Pornichet, 1992)

Clouard, E., 'Le Protestantisme en Bretagne au XVIe siècle. Etude historique et critique' Mémoires de la Société d'Histoire et d'Archéologie de Bretagne, XVIII (1937) 21-169 and XIX (1938) 1-64

Cloulas, I., Henri II (Paris, 1985)

Collins, J.B., Classes, Estates and Order in Early Modern Brittany (Cambridge, 1994)

Constant, J.-M., Nobles et paysans en Beauce aux XVIe et XVIIe siècles (Thesis, Lille, 1981)

Constant, J-.M., Les Guise (Paris, 1984)

Constant, J.-M., La vie quotidienne de la noblesse française aux XVIe-XVIIe siècles (Paris, 1985)

Constant, J.-M., 'Les barons Français pendant les guerres de religion' in Quatrième centenaire de la bataille de Coutras (Pau, 1988) 49-62

Constant, J.-M., La société française aux XVIe, XVIIe et XVIIIe siècles (Paris, 1994)

Constant, J.-M., La noblesse en liberté XVIe-XVIIe siècles (Rennes, 2004)

Contamine, P., "Un aspect de la "tyrannie" de Louis XI. Variations sur le thème du "roi marieur"' in La femme au Moyen Age (eds Rouche, M. and Heuclin, J., Maubeuge, 1990) 431-442

Contamine, P., Des pouvoirs en France 1300-1500 (Paris, 1992)

Contamine, P., La noblesse au royaume de France de Philippe le Bel à Louis XII. Essai de synthèse (Paris, 1997)

Contamine, P. and Mattéoni, O. (eds), La France des principautés. Les chambres des comptes, XIVe et XVe siècles (Paris, 1996)

Cosneau, E., Le Connétable de Richemont (Artur de Bretagne) (1393-1458) (Paris, 1886)

Couanier de Launay, M.E.L., Histoire de Laval (2nd edition, Laval, 1894)

Crouzet, D., 'Recherches sur la crise de l'aristocratie en France au XVIe siècle: les dettes de la maison de Nevers' Histoire, Economie et Société, 1 (1982) 7-50

Curry, A., 'English Armies in the Fifteenth Century' in Arms, Armies and Fortifications in the Hundred Years War (Woodbridge, 1994) 39-68

Daussy, H., 'Les huguenots entre l'obéissance au roi et l'obéissance à Dieu' Nouvelle Revue du XVIe siècle, 22 (2004) 49-69

D’Arcy, J.D. Boulton, Knights of the Crown. The Monarchical Orders of Knighthood in Later Medieval Europe, 1315-1520 (Bury St Edmunds, 1987)

Demurger, A., Temps de crises, temps d'espoirs XIVe-XVe siècle (Paris, 1990) 
Descimon, R., 'Chercher de nouvelles voies pour interpréter les phénomènes nobiliaires dans la France moderne. La noblesse, "essence" ou rapport social?' Revue d'Histoire Moderne and Contemporaine, 46 (1999) 5-21

Devèze, M., La vie de la forêt Française au XVIe siècle (Paris, 1961)

Dewald, J., Pont-St-Pierre, 1398-1789: Lordship, Community, and Capitalism in Early Modern France (Berkeley, 1987)

Dewald, J., Aristocratic Experience and the Origins of Modern Culture: France 1570-1715 (Berkeley, 1993)

Dewald, J., The European Nobility, 1400-1800 (Cambridge, 1996)

Diegerick, I., 'Notice sur les négociations qui ont eu lieu entre les Etats Généraux et le duc d'Anjou après la tentative ce prince de surprendre Anvers (janvier à avril 1583)' Annales de l'Académie d'Archéologie de Belgique, 13 (1856)

Doran, S., Monarchy and Matrimony. The courtship of Elizabeth I (London, 1996)

Drouot, H., Mayenne et la Bourgogne. Etude sur la ligue (1587-1596) (Dijon, 1937)

Dubois, L., Vitré. Essai sur l'histoire de la ville et de ses seigneurs jusqu'à la révolution de 1789 (Paris, 1839)

Duchemin de Villiers, J.-A., Essais historiques sur la ville et le pays de Laval (Laval, 1843)

Dudoret, L., Seigneurs et seigneuries au pays de Beffou (XVe-XVIIe) (Guingamp, 2000)

Du Fresne de Beaucourt, G., Histoire de Charles VII (Paris, 1881-1891)

Du Halgouet, H., Contribution à l'étude du régime seigneurial dans l'ancienne France: La vicomté et le duché de Rohan et ses seigneurs (Paris, 1921-1924)

Du Halgouet, H., 'Droits honorifiques et prééminences dans les églises en Bretagne' Mémoires de la Société d'Histoire et d'Archéologie de Bretagne, 4 (1923) 31-87

Dupouy, A., Histoire de Bretagne (Paris, 1932)

Duquenne, F., L'entreprise du duc d'Anjou aux Pays-Bas de 1580 à 1584: les responsabilités d'un échec à partager (Villeneuve d'Ascq, 1998)

Durand, Y., 'Clientèles et fidélités dans le temps et dans l'espace' in Hommage à Roland Mousnier: clientèles et fidélités en Europe à l'époque moderne (Paris, 1981) 3-24

Duval, F., La traduction du "Romuleon" par Sébastien Mamerot: étude sur la diffusion de l'histoire romaine en langue vernaculaire à la fin du Moyen âge (Geneva, 2001)

Duval, M., La forêt de Brécilien et ses très anciens usements (Rennes, 1954)

Eraud, D., 'La galerie des comtes de Laval: vous avez dit Pierre Lescot?' Société d'Archéologie et d'Histoire de la Mayenne, 23 (2000) pp. 139-154

Eraud, D., 'Laval: l'enceinte urbaine médiévale' Société d'Archéologie et d'Histoire de la Mayenne, 5 (1983) pp. 31-47

Eurich, S.A., The Economics of Power: the Private Finances of the House of FoixNavarre-Albret during the Religious Wars (Kirksville, 1994)

Favier, J., La Guerre de Cent Ans (Paris, 1980)

Febvre, L., Philippe II et la Franche-Comté (Paris, 1911) 
Foucault, M., Les seigneurs de Laval (Laval, 1875)

Fourquin, G., Seigneurie et féodalité au Moyen Age (Paris, 1970)

Frain, E., Epinay en Champeaux. Sa splendeur au XVIe siècle, son état de ruine au XVIIIe, sa restauration de nos jours (Vitré, 1908)

Gabory, E., Le Meurtre de Gilles de Bretagne 1450 (Paris, 1928)

Gabory, E., L'Union de la Bretagne à la France. Anne de Bretagne, duchesse et reine (Paris, 1941)

Gallet, J., La seigneurie bretonne, 1450-1680. L'exemple du Vannetais (Paris, 1983)

Garrisson, J., Royauté, renaissance et réforme 1483-1559 (Paris, 1991)

Gastines-Dommaigne, Comte de, Les Laval à l'armée de Charles VII (Paris, 1957)

Gaussin, P.-R., Louis XI: un roi entre deux mondes (Paris, 1988)

Gaussin, P.-R., 'Les conseillers de Louis XI (1461-1483)' in Contamine, P. and Chevalier, B. (eds), La France de la fin du XVe siècle. Renouveau et Apogée (Paris, 1985) 105-134

Gaussin, P.-R., 'Les conseillers de Charles VII (1418-1461). Essai de politologie historique' Francia, 10 (1982) 67-130

Germain, R., Les campagnes Bourbonnaises à la fin du Moyen-Age (1370-1530) (Clermont-Ferrand, 1987)

Gicquel, Y., Alain IX de Rohan (1382-1462): Un grand seigneur de l'Age d'Or de la Bretagne (Paris, 1986)

Gicquel, Y., Jean II de Rohan (1452-1516) ou l'indépendance brisée de la Bretagne (Paris, 1994)

Gonzalez, E., Un prince en son hôtel: les serviteurs des ducs d'Orléans au XVe siècle (Paris, 2004)

Goubert, P., Beauvais et les Beauvaisis de 1600 à 1730: Contribution à l'histoire sociale de la France du XVIIe siècle (Paris, 1960)

Gousset, J.-M., 'Les fortifications urbaines de Laval: XIIIe-XVe siècle' Société d'Archéologie et d'Histoire de la Mayenne, 22 (1999) 37-62

Grand, R., 'L'après guerre en Bretagne au XVe siècle' Mémoires de la Société d'Histoire et d'Archéologie de Bretagne, 2 (1921) 9-36

Greengrass, M., 'Noble affinities in early modern France: the case of Henri I de Montmorency' European History Quarterly, 16 (1986) 275-311

Greengrass, M., 'Property and politics in the sixteenth century: the landed fortune of the constable Anne de Montmorency' French History, 2 (1988) 371-398

Greengrass, M., France in the Age of Henri IV. The Struggle for Stability (2nd edition, London, 1995)

Greengrass, M., 'Functions and limits of political clientism in France before Cardinal Richelieu' in Descimon, R. and Bulst, N. (eds), L'état ou le roi. Les fondations de la modernité monarchique en France (XIVe-XVIIe siècles) (Paris, 1996) 69-82

Guénée, B., Tribunaux et gens de justice dans le bailliage de Senlis à la fin du Moyen Age, vers 1380-vers 1550 (Paris, 1963)

Guillotte, S., Mécénat et art de cour dans la famille de Laval à la fin du Moyen Age (DEA Thesis, Rennes, 2001) 
Harding, R., Anatomy of a Power Elite. The Provincial Governors of Early Modern France (London, 1978)

Harsgor, M., Recherches sur le personnel du conseil du roi sous Charles VIII et Louis XII (Thesis, Paris IV, 1972)

Harsgor, M., 'L'essor des bâtards nobles au XVe siècle' Revue Historique, 253 (1975), 319-353

Harsgor, M., 'Maîtres d'un royaume, le groupe dirigeant français à la fin du XVe siècle' in Contamine, P. and Chevalier, B. (eds), La France de la fin du XVe siècle. Renouveau et Apogée (Paris, 1985) 135-146

Heers, J., Gilles de Rais (Paris, 1994)

Higman, F., Piety and People: Religious Printing in French 1511-1551 (Aldershot, 1996)

Holt, M.P., 'Patterns of clientèle and economic opportunity at court during the Wars of Religion: the household of François, duke of Anjou' French Historical Studies, 13 (1984) 305-322

Holt, M.P., The duke of Anjou and the Politique Struggle during the Wars of Religion (Cambridge, 1986)

Holt, M.P., The French Wars of Religion, 1562-1629 (Cambridge, 1995)

Huppert, G., Les Bourgeois Gentilshommes: an Essay on the Definition of Elites in Renaissance France (Chicago, 1977)

Jones, M., Ducal Brittany 1364-1399. Relations with England and France during the Reign of Duke John IV (Oxford, 1970)

Jones, M., The Creation of Brittany: A Late Medieval State (London, 1988)

Jones, M., 'Breton nobility in the service of the state? The case of Guillaume de Rosnyvinen' in Contamine, P. et al, (eds), Guerre et société en France, en Angleterre et en Bourgogne (Lille, 1991) 261-292

Jones, M., 'Les signes du pouvoir: l'ordre de l'Hermine, les devises et les héraults des ducs de Bretagne au XVe siècle' Mémoires de la Société d'Histoire et d'Archéologie de Bretagne, 68 (1991) 141-173

Jones, M., 'The late medieval state and social change: a view from the duchy of Brittany' in Descimon, R. and Bulst, N. (eds), L'état ou le roi. Les fondations de la modernité monarchique en France (XIVe-XVIIe siècles) (Paris, 1996) 117-144

Jones, M., 'The Material Rewards of Service in Late Medieval Brittany: Ducal Servants and their Residences' in Curry, A. and Matthew, E. (eds), Concepts and Patterns of Service in the Later Middle Ages (Woodbridge, 2000) 119-144

Jouanna, A., 'Protection des fidèles et fidélité au roi: l'exemple de Henri Ier de Montmorency-Damville' in Durand, Y. (ed.), Hommage à Roland Mousnier: clientèles et fidélités en Europe à l'époque moderne (Paris, 1981) 279-296

Jouanna, A., Le devoir de révolte. La noblesse française et la gestion de l'état moderne (1559-1661) (Paris, 1989)

Jouanna, A., 'Des réseaux d'amitié aux clientèles centralisées: les provinces et la cour (France, XVIe-XVIIe siècle)' in Giry-Deloison, C. and Mettam, R. (eds), Patronages et clientèlismes 1550-1750 (France, Angleterre, Espagne, Italie) (Lille, 1990) 21-38 
Jouanna, A., 'Des "gros et gras" aux "gens d'honneur"' in Chaussinand-Nogaret, G. (ed.), Histoire des élites en France du XVIe au XXe siècle (Paris, 1991) 17-141

Jouanna, A., 'Réflexions sur les relations inter nobiliaires en France au XVIe et XVIIe siècles' French Historical Studies, 17 (1992) 872-881

Kalas, R.J., 'Marriage, clientage, office holding, and the advancement of the early modern French nobility: the Noailles family of Limousin' Sixteenth Century Journal, 27 (1996), 365-383

Kerhervé, J., Les gens de finances des ducs de Bretagne, 1365-1491. Catalogue prosopographique (Thesis, Paris IV, 1986)

Kerhervé, J., L'état Breton aux 14 e et 15 e siècles. Les ducs, l'argent et les hommes (Paris, 1987)

Kettering, S., 'Patronage in early modern France' French Historical Studies, 17 (1992) 839-862

Kettering, S., Patrons, Brokers and Clients in Seventeenth-Century France (New York, 1986)

Kettering, S., 'Clientage during the French Wars of Religion' Sixteenth Century Journal, 20 (1989) 221-239

Kettering, S., 'Friendship and clientage in early modern France' French History, 6 (1992) 139-158

Klötgen, J., 'Une charte retrouvée de Guy XV de Laval (1491). Notice historique sur les armoiries de Laval' Revue Historique et Archéologique du Maine, 148 (1997) 209-232

Labande-Mailfert, Y., Charles VIII et son milieu (Paris, 1975)

Labatut, J.-P., Les ducs et pairs de France au XVIIe siècle: étude sociale (Paris, 1972)

La Borderie, Le Moyne A. de, Le Calvinisme à Vitré (Rennes, 1851)

La Borderie, Le Moyne A. de, Le complot breton de 1492 (Nantes, 1882)

La Borderie, Le Moyne A. de, 'La Trémoïlle et Laval-Vitré' Revue de Bretagne and de Vendée, 32 (1888) 120-134

La Borderie, Le Moyne A. de, Jean Meschinot: Sa vie et ses oeuvres, ses satires contre Louis XI (Paris, 1896)

La Borderie, Le Moyne A. de, L'architecture militaire du Moyen Age en Bretagne (Reprint, 1991)

La Borderie, Le Moyne A. de and Pocquet du Haut-Jussé, B., Histoire de Bretagne (Rennes, 1896-1914) IV, p. 308

Langlois, M., Etude historique, administrative et économique de la seigneurie de Quintin jusqu'en 1682 (Thesis, Ecole des Chartes, 1977)

Langlois, M., 'La forêt de Quintin aux XVe-XVIe siècles' Mémoires de la Société d'Histoire et d'Archéologie de Bretagne, 70 (1993) 5-22

Laronze, C., Essai sur le régime municipal en Bretagne pendant les guerres de religion (Reprint, Geneva, 1981)

Lartigaut, J., 'L'image du baron au début du XVIe siècle: Caumont contre Thémines' Annales du Midi, 94 (1982) 151-171 
La Touche, R., Histoire du comté du Maine pendant le Xe et XIe siècle (Paris, 1910)

Le Dru, A., Anne de Laval et Guy Turpin (Paris, 1888)

Le Fizelier, J., La bataille de la Brossinière, septembre 1423 (Mamers, 1876)

Leguay, J.-P., Un réseau urbain au moyen âge: les villes du duché de Bretagne aux XIVe et XVe siècles (Paris, 1981)

Leguay, J.-P. and Martin, H., Fastes et malheurs de la Bretagne ducale, 1213-1532 (Rennes, 1982)

Lemarignier, J.-F., La France médiévale: institutions et société (Paris, 1970)

Le Mené, M., Les campagnes angevines à la fin du Moyen Age (1350-1530) (Nantes, 1982)

Lemonnier, H., Les guerres d'Italie. La France sous Charles VIII, Louis XII et François Ier (1492-1547) (Paris, 1911)

Le Page, D. and Nassiet, M., L'Union de la Bretagne à la France (Morlaix, 2003)

Le Roux, N., 'The catholic nobility and political choice during the league, 15851594: the case of Claude de La Châtre' French History, 8 (1994) 34-50

Le Roux, N., La Faveur du roi. Mignons et coutisans au temps des derniers Valois (vers 1547-vers 1589) (Seyssel, 2000)

Le Roux, N., 'Honneur et fidélité. Les dilemmas de l'obeissance nobiliaire au temps des troubles de Religion' Nouvelle Revue du XVIe siècle, 22 (2004) 127-146

Lewis, P.S., 'The problems of prosopography in later medieval France' in Autrand, F., Prosopographie et genèse de l'état moderne (Paris, 1986) 281-288

Lewis, P.S., 'Decayed and non feudalism in later medieval France' Bulletin of the Institute of Historical Research, 37 (1963) 157-184

MacCaffrey, W.T., 'The Anjou match and the making of Elizabethan foreign policy' in Clark, A. (ed.), The English Commonwealth, 1547-1640 (Leicester, 1979)

Martin, G., Histoire et généalogie des maisons de Rohan, de Chabot et de RohanChabot (Paris, 1977)

Mattéoni, O., Servir le prince. Les officiers des ducs de Bourbon à la fin du MoyenAge (1356-1523) (Paris, 1998)

Maucourt de Bourjolly, C., Mémoire chronologique des seigneurs fondateurs, du château et de la ville de Laval (eds Le Fizelier, J. and Bertrand de Broussillon, L.-A., Laval, 1886)

Maynard, D. de and Eraud, D., 'Armoiries de Laval et de ses seigneurs' Société d'Archéologie et d'histoire de la Mayenne, 18 (1995) 127-133

Minois, G., Anne de Bretagne (Paris, 1999)

Miramont, C., Bruno deRoade, évêque de Couserans (Nîmes, 1999) p. 38

Moulard, P., Monographie de la Chapelle-Rainsouin (Mamers, 1890)

Mousnier, R., 'Les Concepts d'ordres, d'états, de fidélité et de monarchie absolue en France de la fin du XVe siècle à la fin du XVIIIe' Revue Historique, 247 (1972) 289-312

Mousnier, R., 'Les fidélités et les clientèles en France aux XVIe, XVIIe et XVIIIe siècles’ Histoire Sociale, 15 (1982) 35-46 
Mussat, A., 'Le château de Vitré et l'architecture des châteaux bretons du XIVe au XVIe siècle' Bulletin Monumental, 133 (1975) 131-164

Nassiet, M., 'Signes de parenté, signes de seigneurie: un système idéologique (XVeXVIe siècle)' Mémoires de la Société d'Histoire et d'Archéologie de Bretagne, 68 (1991) 175-232

Nassiet, M., Noblesse et Pauvreté: La petite noblesse en Bretagne, XVe-XVIIIe siècle (Rennes, 1993)

Nassiet, M., 'Nom et blason. Un discours de la filiation et de l'alliance (XIVe-XVIIIe siècle)' L'Homme 129, 34 (1994) 5-30

Nassiet, M., 'Réseaux de parenté et types d'alliance dans la noblesse (XVe-XVIIe siècles)' Annales de Démographe Historique, (1995) 105-123

Nassiet, M., 'Fidélités et perspectives dynastiques dans la noblesse bretonne lors de la crise de succession (1470-1491)' in Kerhervé, J. (ed.), Noblesses de Bretagne du Moyen Age à nos jours (Rennes, 1998) 103-128

Nassiet, M., Parenté, noblesse et états dynastiques, XVe-XVIe siècles (Paris, 2000)

Neuschel, K.B., Word of Honor: Interpreting Noble Culture in Sixteenth Century France (New York, 1989)

Neuschel, K.B., The Prince of Condé and the Nobility of Picardy: a Study of the Structure of Noble Relationships in Sixteenth Century France (Thesis, Brown, 1982)

Noël, J.-F., 'Seigneurie et propriété urbaine sous l'Ancien Régime. Autour de la maison de Bertrand d'Argentré à Vitré' Revue d'Histoire Moderne and Contemporaine, 38 (1991) 177-204

Olland, H., La baronnie de Choiseul à la fin du moyen âge (1452-1525) (Nancy, 1980)

Pacault, A., 'Serviteurs et fidèles du duc de Montmorency en sa baronnie de Châteaubriant autour de 1600' Mémoires de la Société d'Histoire et d'Archéologie de Bretagne, 66 (1989) 79-117

Pannier, J., 'Anne d'Alègre, dame de Coligny et comtesse de Laval, puis maréchale de Fervaques, marquise d'Allègre' Bulletin de la Société Hisorique de Paris, 58 (1925) 132-142

Pebay-Clottes, I., 'Eglise catholique et églises réformées dans le comté de Foix (1559-1643)' Bul. soc. Arieg. sciences, lettres et arts (1988) 93-216

Pettegree, A.D.M., Europe in the Sixteenth Century (London, 2002)

Pichot, D., Le Bas-Maine du Xe au XIIIe siècle: étude d'une société (Laval, 1995)

Pocquet du Haut Jussé, B.-A., Les Papes et les ducs de Bretagne. Essai sur les rapports du Saint Siège avec un état (Paris, 1928)

Pointeau, C., 'Deux capitaines manceaux de l'époque des guerres de Religion: le sire de Pescheseul et monsieur de la Patrière' Revue Historique et Archéologique du Maine, 1 (1876) 609-629

Pointeau, C., Certificats de l'état religieux de la noblesse du bas Maine en 1577 (Laval, 1885)

Poirier, J.-M., La musique au 16e siècle dans l'entourage des comtes de Laval in Walsby, M.N. (ed.), La Renaissance en Mayenne (Laval, 2007) 
Pothain, A.-F., Les Seigneuries de Ranrouët-Asserac et Faugaret à la Fin du MoyenAge (MA Thesis, Nantes, 1993)

Potter, D., 'Marriage and Cruelty among the Protestant Nobility in Sixteenth Century France: Diane de Barbançon and Jean de Rohan, 1561-7' European History Quarterly 20 (1990), 5-38

Potter, D., 'The Luxembourg inheritance: the house of Bourbon and its lands in Northern France during the sixteenth century' French History, 6 (1992) 24-62

Potter, D., War and Government in the French Provinces: Picardy 1470-1560 (Cambridge, 1993)

Potter, D., A History of France 1460-1560: The Emergence of a Nation State (London, 1995)

Quicherat, J., Procès de condamnation et de réhabilitation de Jeanne d'Arc dite la Pucelle (Paris, 1849)

Ritter, R., La soeur d'Henri IV. Catherine de Bourbon 1559-1604 (Paris, 1985)

Roelker, N.L., 'The appeal of Calvinism to French noblewomen in the sixteenth century' Jounal of Interdisciplinary History, 2 (1972) 391-418

Romier, L., Le royaume de Catherine de Médicis. La France à la veille des guerres de Religion (Paris, 1925)

Rouard, C., Le conseil ducal de Bretagne au début du règne de François II (années 1459 et 1460) (MA Thesis, Nantes, 1991)

Russell Major, J., 'Noble income, inflation and the Wars of Religion in France' American Historical Review, 86 (1981) 21-48

Russel Major, J., 'Bastard feudalism and the kiss: Changing social mores in late medieval and early modern France' Journal of Interdisciplinary History, 17 (1987) 509-535

Russell Major, J., 'Vertical ties through time' French Historical Studies, 17 (1992) 863-871

Russell Major, J., From Renaissance Monarchy to Absolute Monarchy: French Kings, Nobles and Estates (Baltimore, 1994)

Schalk, E., From Valor to Pedigree: Ideas of Nobility in France in the Sixteenth and Seventeenth Centuries (Princeton, 1986)

Schalk, E., "The court as "civilizer" of the nobility: nobles attitudes and the court in France in the late sixteenth and early seventeenth century' in Asch, R. and Birke, A. (eds), Princes, Patronage, and the Nobility: the Court at the Beginning of the Modern Age c.1450-1650 (Oxford, 1991) 245-263

Sée, H., Les états de Bretagne au XVIe siècle (Paris, 1895)

Stone, L., The Crisis of the Aristocracy, 1558-1641 (Oxford, 1967)

Sutherland, N M., The Massacre of St Bartholomew and the European Conflict, 1559-1572 (London, 1973)

Tallandier, C., Histoire ecclésiastique et civile de Bretagne (Paris, 1750-1756)

Tréverdy, J., Les Bretons compagnons du connétable de Richemont (reedition Vannes, 1909) 
Tréverdy, J., 'Anne comtesse de Laval, Jacques d'Espinay, évêque de Rennes et Pierre Landais, trésorier de Bretagne' Bulletin de la Commission Historique et Archéologique de la Mayenne, 20 (1904) 473-486

Tygielski, W., 'A faction which could not Lose' in Maczak (ed.), Klientel-systeme im Europa der frühen Neuzeit (Munich, 1988) 177-201

Vaissière, P. de, Gentilshommes campagnards de l'ancienne France (Paris, 1904) Vale, M.G.A., War and Chivalry. Warfare and Aristocratic Culture in England, France and Burgundy at the End of the Middle Ages (London, 1981)

Vaurigaud, B., Essai sur l'histoire des églises reformées de Bretagne 1535-1808 (Paris, 1870)

Walsby, M.N., 'Un grand seigneur protestant durant les guerres de religion: la carrière politique et militaire de Guy XIX, comte de Laval (1580-1586)' Société d'Archéologie et d'Histoire de la Mayenne, 22 (1999) 87-106

Walsby, M.N., The Comtes de Laval 1429-1605: Land, Lineage and Patronage in Late Medieval and Renaissance France (Thesis, University of Kent at Canterbury, 2001)

Walsby, M.N., 'Préférer miséricorde: La violence et les lettres de rémission des comtes de Laval au XVe siècle' Oribus, 56 (2002) 39-46

Walsby, M.N., 'Dynastic strategy and clientage: the rise of the house of Espinay in fifteenth and sixteenth century France' Medieval History (1-2002) 83-97

Walsby, M.N., 'La famille de Laval et Anne de Bretagne 1488-1513' in Pour en finir avec Anne de Bretagne? (ed. Le Page, D., Nantes, 2004) 109-124

Walsby, M.N. (ed.), La Renaissance en Mayenne (Laval, 2007)

Wanegffelen, T., Ni Rome ni Genève: Des fidèles entre deux chaires en France au XVIe siècle (Paris, 1997)

Weary, W.A., Royal Policy and Patronage in Renaissance France: The Monarchy and the House of La Trémoïlle (Thesis, Yale, 1972)

Weary, W.A., 'La maison de la Trémoïlle pendant la renaissance: une seigneurie agrandie' in Contamine, P. and Chevalier, B. (eds), La France de la fin du XVe siècle. Renouveau et Apogée (Paris, 1985) 197-212

Weary, W.A., 'The house of La Trémoïlle, fifteenth through eighteenth centuries: Change and adaptation in a French noble family' Journal of Modern History, 49 (1977) Demand supplement 1001-1038, p. 1025

Wedgwood, C.V., William the Silent (London, 1960) p. 226

Wood, J.B., 'The Impact of the Wars of Religion: A View of France in 1581', Sixteenth Century Journal, 2 (1984)

Wood, J.B., The Nobility of the Election of Bayeux 1463-1666, Continuity through Change (Princeton, 1980)

Yardeni, M., La conscience nationale en France pendant les guerres de religion (1559-1598) (Louvain, 1971)

Zemon Davis, N., The Gift in Sixteenth Century France (Oxford, 2000) 